\title{
Non-Market Ecosystem Services of Agricultural Land and Priorities Towards a More Sustainable Agriculture in Italy
}

Article · March 2016

\section{CITATION}

1

5 authors, including:

Vassilis George Aschonitis

University of Ferrara

51 PUBLICATIONS 114 CITATIONS

SEE PROFILE

Giuseppe Castaldelli

University of Ferrara

80 PUBLICATIONS 780 CITATIONS

SEE PROFILE
READS

135

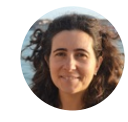

Elena Gissi

Università luav di Venezia

21 PUBLICATIONS 11 CITATIONS

SEE PROFILE

E. A. Fano

University of Ferrara

64 PUBLICATIONS 885 CITATIONS

SEE PROFILE

Some of the authors of this publication are also working on these related projects:

Urban metabolism accounts for building Waste management Innovative Networks and Strategies 


\title{
Non-Market Ecosystem Services of Agricultural Land and Priorities Towards a More Sustainable Agriculture in Italy
}

\author{
Mattias Gaglio ${ }^{1}$, Vassilis Aschonitis ${ }^{1, *}$, Elena Gissi ${ }^{2}$, Giuseppe Castaldelli ${ }^{1}$ and \\ Elisa-Anna Fano ${ }^{1}$
}

${ }^{1}$ Department of Life Sciences and Biotechnology, University of Ferrara, Ferrara, Italy and ${ }^{2}$ Universita IUAV di Venezia, Department of Design and Planning in Complex Environments, Venice, Italy

\begin{abstract}
Ecosystems provide a range of services, commonly called Ecosystem Services (ESs), which are of fundamental importance to human well-being, health, livelihoods, and survival. One of the largest and most productive ecosystems is agricultural land. Agro-Ecosystems provide a range of services directly linked to the market (e.g. food and raw materials production) but also many others of high ecological value, which have an indirect economical contribution in the GDP (non-market ESs). These non-market services are not usually taken into account in the development of agricultural management strategies while their contribution is reduced due to non-sustainable agricultural practices. The aim of the study is to assess the potential economic contribution of the non-market services at national, regional, and provincial level in Italy and to propose a simplified index-based method for setting priorities at different scales of administration units for the implementation of sustainable agricultural practices (SAPs). The results of the study showed that the potential non-market value of agro-ecosystem services (AESs) in Italy can reach $\sim 46.2$ billion USD\$2007. This estimate shows that non-market AESs can play an important role in the national GDP if SAPs are followed. Finally, a priority ranking scheme for the implementation of SAPs was proposed at regional and provincial level which can be a valuable decision support tool for promoting sustainable agriculture policies.
\end{abstract}

Keywords: Ecosystem services, Agricultural land, Non-market services, Priority index.

\section{INTRODUCTION}

Ecosystems provide a range of services, which are of fundamental importance to human well-being, health, livelihoods, and survival. The economical contribution of such services can be evaluated using valuation methods such as those provided by Costanza et al. [1,2] and de Groot et al. [3] etc., which are extremely useful tools in the development of landscape management plans [4]. These methods consider fourteen main types of ecosystems/biomes (such as marine, coral reefs, coastal systems, coastal wetlands, inland wetlands, freshwater river/lakes, tropical forests, temperate forests, woodlands, grasslands, deserts, polar regions, cultivated lands and urban areas) and many other sub-biomes. For each biome, monetary values have been set based on the ecosystem services (ESs) they provide, which are divided in four main categories, such as provisioning, regulation, supporting and cultural services. One of the main problems is that the economical value of many services provided by the ES approach cannot be validated easily because it is not directly linked to the market (non-market services). For example, the effects of forests on erosion control, water supply etc., are representative cases of non-market ecosystem services.

${ }^{*}$ Address correspondence to this author at the Department of Life Sciences and Biotechnology, University of Ferrara, Ferrara, Italy; schvls@unife.it
One of the largest and most productive ecosystems are agricultural lands, which are both providers and consumers of ecosystem services [5]. Agro-ecosystem services (AESs) can also provide a wide range of nonmarket services of high ecological value and indirect profit that are not usually taken into account in the development of agricultural management strategies. In long-term, such strategies lead to environmental quality degradation due to unsustainable agricultural practices that aim to increase the high direct profit $[6,7]$.

The aim of the study is to assess the potential economic contribution of the non-market services at national, regional, and provincial level in Italy and to propose a simplified index-based method for setting priorities at different scales of administration units for the implementation of sustainable agricultural practices. The results of the study can be used as tools for decision making towards a more sustainable agriculture.

\section{AGRO-ECOSYSTEM SERVICES (AESs)}

\subsection{Provisioning Services}

The contribution of agricultural ecosystems in the provisioning services is mainly associated to food production, production of raw materials (fiber and biomass for bioenergy), provision of genetic resources, and water supply. Farmers' efforts are focused on provisioning services since they are strongly linked to 
the market that generates income. Especially food and raw materials production are fundamental since they are considered the most important elements of management strategies to support the growth of local economies in developed countries through short production chains $[8,9]$.

The role of agriculture in the production of raw materials dates thousands years back where plant fibers were used for clothing, artifacts manufacturing, building etc. (e.g. papyrus, ropes, baskets, straw bricks etc.). Fibers can be produced from seeds, leaves, bast fibres, barks, fruits and stalks (e.g. cotton, bamboo, jute, coir, bagasse, hemp, flax, kapok, sisal, jute, kenaf) $[10,11]$. The last decades, the production of raw materials (biomass) has also been used for energy production since biomass can be converted into three main product types of bioenergy: electrical/heat energy, transport fuel and chemical feedstock $[12,13]$.

As concerns the AES from genetic resources, agricultural lands host a vast variety of soil microorganisms/bacteria and invertebrates, plants, animals, insects, fungi, viruses etc., which are sources of unique biological material that can be used in medicine, products for materials science, genes for genetic improvement etc. [14].

The contribution of agricultural land on water supply is mainly associated to the reduction of water losses by runoff and water evaporation from soil that contribute to higher water retention and groundwater recharge. The reduction of runoff is succeeded through typical land leveling, contour barriers and ditches, bench terraces, furrow channels and drainage canals [15.16] while evaporation losses can be reduced by the crop canopy or by synthetic geotextiles and organic mulching materials (e.g. pine bark, vine pruning residues, straw etc.) deposited on the soil surface [17]. The aforementioned interventions in combination with best management tillage practices and cover or winter crops can significantly increase the specific AES $[18,19]$.

\subsection{Regulation Services}

The most important regulation services provided by agro-ecosystems are climate regulation, erosion control, waste treatment, and biological control. Climate regulation considers the regulation of global temperature, precipitation, and other biologically mediated climatic processes at global or local levels [1]. The contribution of croplands in this AES type is associated to the regulation of green house gasses such as carbon dioxide through carbon sequestration $[20,21]$ and to the absorption of solar radiation for photosynthesis. Erosion control is associated with the same interventions for the AES of water supply (see previous section) that reduce runoff, particularly in steep slopes. In the case of waste treatment, the contribution of agricultural land is mainly associated to the use of wastes as fertilizers (e.g. manures), mineralization of organic matter, and nutrient absorption through microbial and aquatic flora processes in the field (e.g. rice fields) and in the drainage canals [22-25]. The AES of biological control concerns the control of pests and diseases based on natural enemies' interactions $[26,27]$.

\subsection{Supporting Services}

The supporting AESs include pollination and soil formation. Pollination provided by animals (mainly insects) significantly contributes in sustaining the thirtyfive percent of global production from crops including at least 800 cultivated plants [28]. Pollination also depends on the presence of natural habitats surrounding the farm. Within the crop field, the conservation of crop genetic diversity by promoting differentiated cultural patterns has shown to be useful not only for pollination but also for pest and disease management [29]. The contribution of agricultural land to the AES of soil formation can be performed through the following processes: a) soil weathering by crops' rooting systems and rhizosphere microflora [30-32], b) soil fragmentation/aggregation by the combined effects of tillage, incorporation of residues and intense wetting-drying cycles due to irrigation especially during summer [33-35].

\subsection{Cultural Services}

Additional services provided by agricultural landscapes include cultural benefits whose valuation can be especially difficult [36]. Cultural services are of significant importance for the role they can play in regional economies of local communities $[37,38]$. This AES is associated to tourism activities (e.g. agricultural museums and exhibition parks, traditional localities, agro-tourism etc.) related to cultural heritage, new technologies, recreation activities such as hunting, or other artistic activities related to agricultural landscape (e.g. professional photography, painting etc.).

\subsection{Degradation of AESs}

The aforementioned AESs are of significant ecological and economical value when agronomic practices are performed with respect to environmental quality. 
Unfortunately, the intensification of agriculture during the last decades through monoculture systems, extensive use of agrochemicals and intensive tillage has led to extensive deterioration of environmental quality. These activities can succeed high direct economic profit through specific provisioning services (e.g. food production and raw materials) but at the same time are responsible for a) the loss of biodiversity that supports genetic resources and pollination services [28,39], b) extremely high water consumption with a negative impact on water supply (e.g. reduction of ground and surface water reserves, saltwater intrusion in lowlands etc.) $[40,41]$, c) water pollution and eutrophication by nutrients and agrochemicals losses with severe impact on water supply and waste treatment services [42], d) nitrous oxides emissions (green house gas) which negatively affect climate regulation services [43] and e) exhaustive absorption of soil macro and micro nutrients and degradation of soil physico-chemical properties that may lead to gradual decline of soil quality through salinization, codification or desertification $[44,45]$. The aforementioned environmental problems suggest an extensive negative impact especially on non-market AESs. Thus, integrated management strategies towards a more sustainable agriculture are required in order to preserve and increase the potential value of nonmarket AESs.

\section{DATA AND METHODS}

\subsection{Data}

The analysis was performed for the Italian territory, which is divided in 20 administrative regions and 110 provinces, using the most recent Corine Land Cover raster map of 2012 (CLC2012) developed by the European Environment Agency (EEA). The CLC2012 is provided with a geometric accuracy better than $100 \mathrm{~m}$ and a thematic accuracy of at least $85 \%$ (http://land. copernicus.eu/pan-european/corine-land-cover). Agricultural land was extracted by the level 3 classification of CLC2012 at national, regional, and provincial level. The administrative boundaries of the Italian country, regions and provinces were obtained by the GADM database (http://www.gadm.org).

Additional data of the period 2010-2012 about the economical contribution of agriculture in the national GDP of Italy were also used. The data were obtained from FAO database (http://faostat.fao.org/site/613/ DesktopDefault.aspx?PagelD=613\#ancor). The economic data were converted to USD\$2007 values using the online monetary inflation calculator (http://www. usinflationcalculator.com/) in order to be comparable with the monetary units used in ESs approach of Costanza et al. [2].

\subsection{AESs Assessment and Priority of Sustainable Agriculture Index}

For AESs assessment, the agricultural land coverage was multiplied by the monetary values of each AES in USD $\$ 2007$ proposed by Costanza et al. [2] for croplands (Table 1). The total value of the agricultural GDP provided by FAO at national level was compared with the total value of AESs in order to assess the potential non-market value of AESs, which can be succeeded in the Italian territory. At regional and provincial level, the non-market value of AESs was assumed proportional due to lack of data of agricultural GDP at administrative unit level.

The target to achieve the potential value of nonmarket AESs requires the development of integrated management strategies towards a more sustainable agriculture. One of the first things needed in order to develop such strategies is to set priorities for the implementation of management schemes. The most typical approach used for this purpose is based on the degree of agricultural pollution based on environmental standards such as those provided by EU Member States (e.g. Nitrates Directive - 91/676/EC, Water Framework Directive - 2000/60/EC etc.). This approach requires continuous and extensive monitoring of environmental parameters of high cost and labor.

On the other hand a more simplified approach is proposed in this study, which is based on the extent of agricultural land within an administrative unit in respect to other administrative ones. The approach is based on a simplified priority index, which uses the \% coverage of agricultural land and the total coverage in area units of a number of administrative units as follows:

$$
\begin{aligned}
& P_{i}=f_{1, i} \times f_{2, i} \\
& f_{1, i}=\frac{x_{i}-x_{\min }}{x_{\max }-x_{\min }}+1 \quad \text { for } x_{\min } \leq x_{i} \leq x_{\max } \\
& f_{2, i}=\frac{y_{i}-y_{\text {min }}}{y_{\text {max }}-y_{\text {min }}}+1 \quad \text { for } y_{\text {min }} \leq y_{i} \leq y_{\text {max }}
\end{aligned}
$$

where $x_{i}$ : is the \% coverage of agricultural land in a province or a region $i$, and $y_{i}$ : is the coverage in area units of agricultural land in a province or a region $i$. The 
minimum and the maximum value of $x$ and $y$ parameters correspond to the respective minimum and maximum values observed in the set of administrative units. $f_{1}$ and $f_{2}$ take always values between 1-2 and thus also $P_{i}$ is restricted between $1-4$. The +1 inside the $f_{1}$ and $f_{2}$ functions is used to avoid having 0 values in the multiplication.

The concept of using the \% coverage $x$ and the total coverage $y$ in area units as two independent parameters is based on the fact that when a region has lower \% of agricultural land then it also has greater \% of natural land. Natural lands provide a high degree of ESs by themselves but also interact with agro-ecosystems mitigating the impact of agricultural activities. The parameter $y$ of agricultural land coverage in area units is used as a substitute of the non-market AESs because in this study they are considered proportional to agricultural land coverage in both regional and provisional scale. The higher the value of $P_{i}$ of a region in respect to others, the higher is the priority to implement sustainable agronomic practices in this region.

\section{RESULTS}

According to CLC2012, the total coverage of agricultural land per province and region is given in Figure $\mathbf{1} \mathbf{a}, \mathbf{b}$ while the respective percentage $\%$ of agricultural land for the respective administrative units is given in Figure 2a,b. The mean total economic contribution of agricultural products of the period 2010-2012 in Italian economy at national level was estimated at 38.383 billion USD\$2007 according to FAO data.

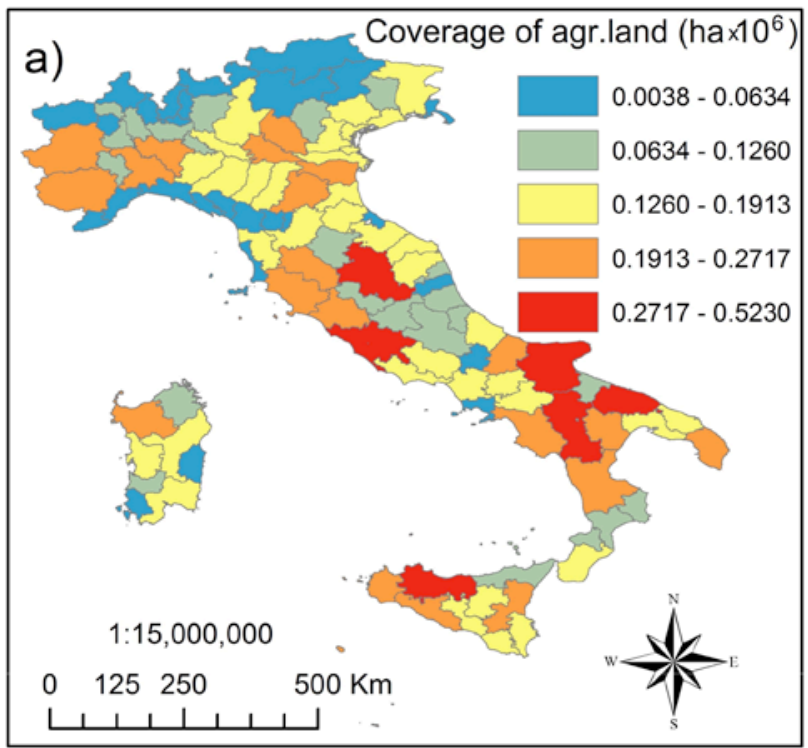

Table 1: Economic Evaluation of ESs for Agricultural Land According to the Benefit-Transfer Approach of Costanza et al. [2]

\begin{tabular}{|c|c|c|}
\hline $\begin{array}{c}\text { Agro-Ecosystem } \\
\text { Services (AESs) }\end{array}$ & $\begin{array}{c}\text { USD\$2007I } \\
\text { ha/Year }\end{array}$ & $\%$ \\
\hline \hline Food production $^{1}$ & 2323 & $41.72 \%$ \\
\hline Raw materials $^{1}$ & 219 & $3.93 \%$ \\
\hline Genetic resources $^{1}$ & 1042 & $18.71 \%$ \\
\hline Water supply $^{1}$ & 400 & $7.18 \%$ \\
\hline Climate regulation $^{2}$ & 411 & $7.38 \%$ \\
\hline Erosion control $^{2}$ & 107 & $1.92 \%$ \\
\hline Waste treatment $^{2}$ & 397 & $7.13 \%$ \\
\hline Biological control $^{2}$ & 33 & $0.59 \%$ \\
\hline Soil formation $^{3}$ & 532 & $9.55 \%$ \\
\hline Pollination $^{3}$ & 22 & $0.40 \%$ \\
\hline Cultural services $^{4}$ & 82 & $1.47 \%$ \\
\hline Total sum $^{2}$ & 5568 & $100 \%$ \\
\hline
\end{tabular}

${ }^{1}$ Provisioning Services, ${ }^{2}$ Regulation services, ${ }^{3}$ Supporting services, ${ }^{4}$ Cultural services.

The total potential contribution of AESs at national level was estimated at 85.111 billion USD $\$ 2007$ taking into account the total value of AESs per unit area provided in Table 1 (5568 USD $\$ 2007 /$ ha/year) while the respective proportions at regional and provincial level are given in Figure $\mathbf{3 a , b}$. If we consider that the AESs of food and raw materials production which are directly linked with the market are together the $45.65 \%$ of the total AESs (Table 1), then according to Costanza et al. [2] the expected value of these AESs provided by

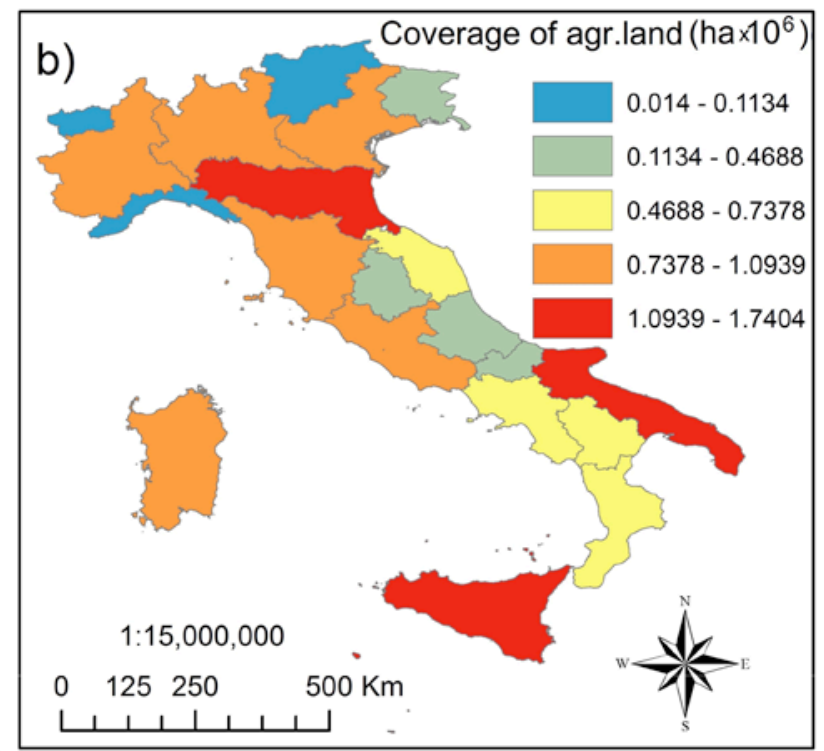

Figure 1: Total coverage of agricultural land a) per province and b) per region in Italy according to CLC2012. 

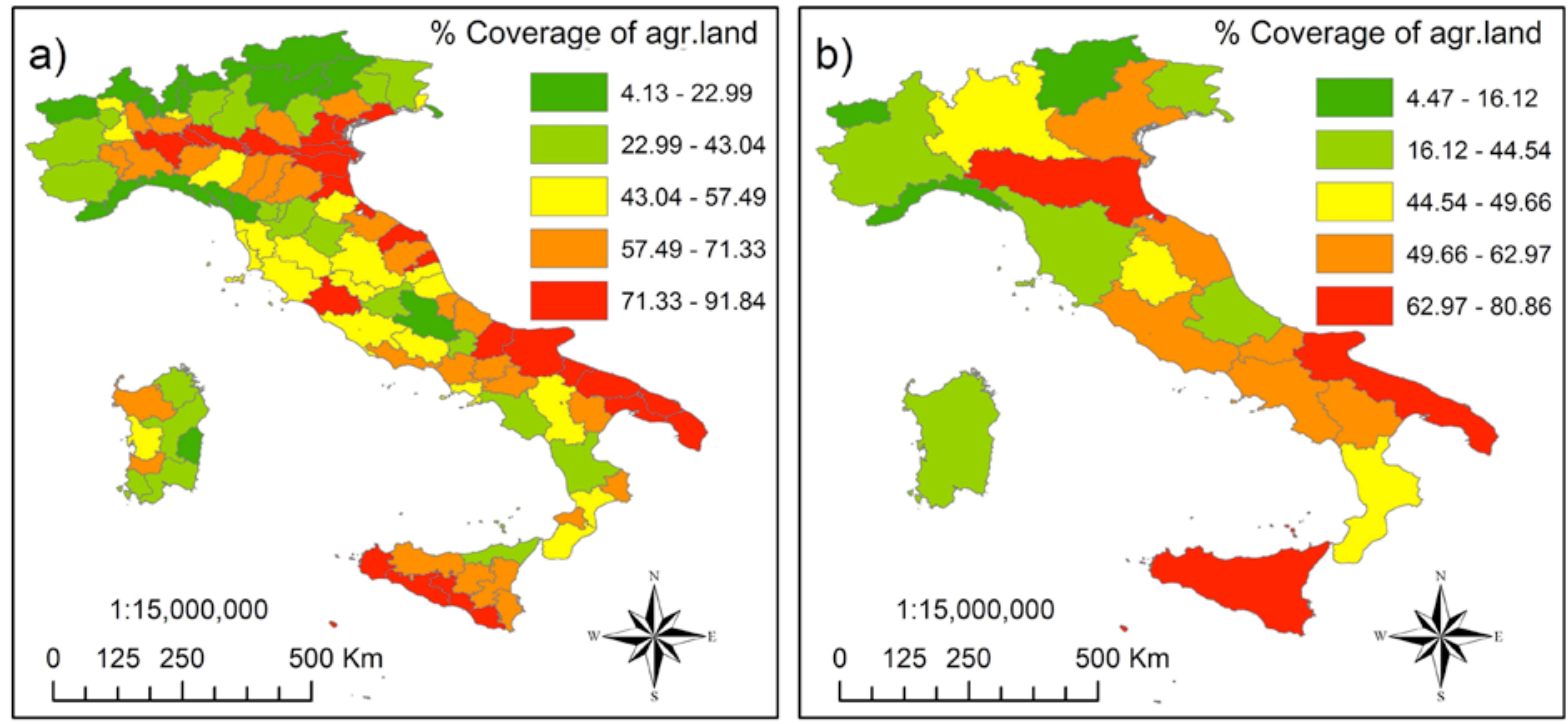

Figure 2: \% coverage of agricultural land a) per province and b) per region in Italy according to CLC2012.
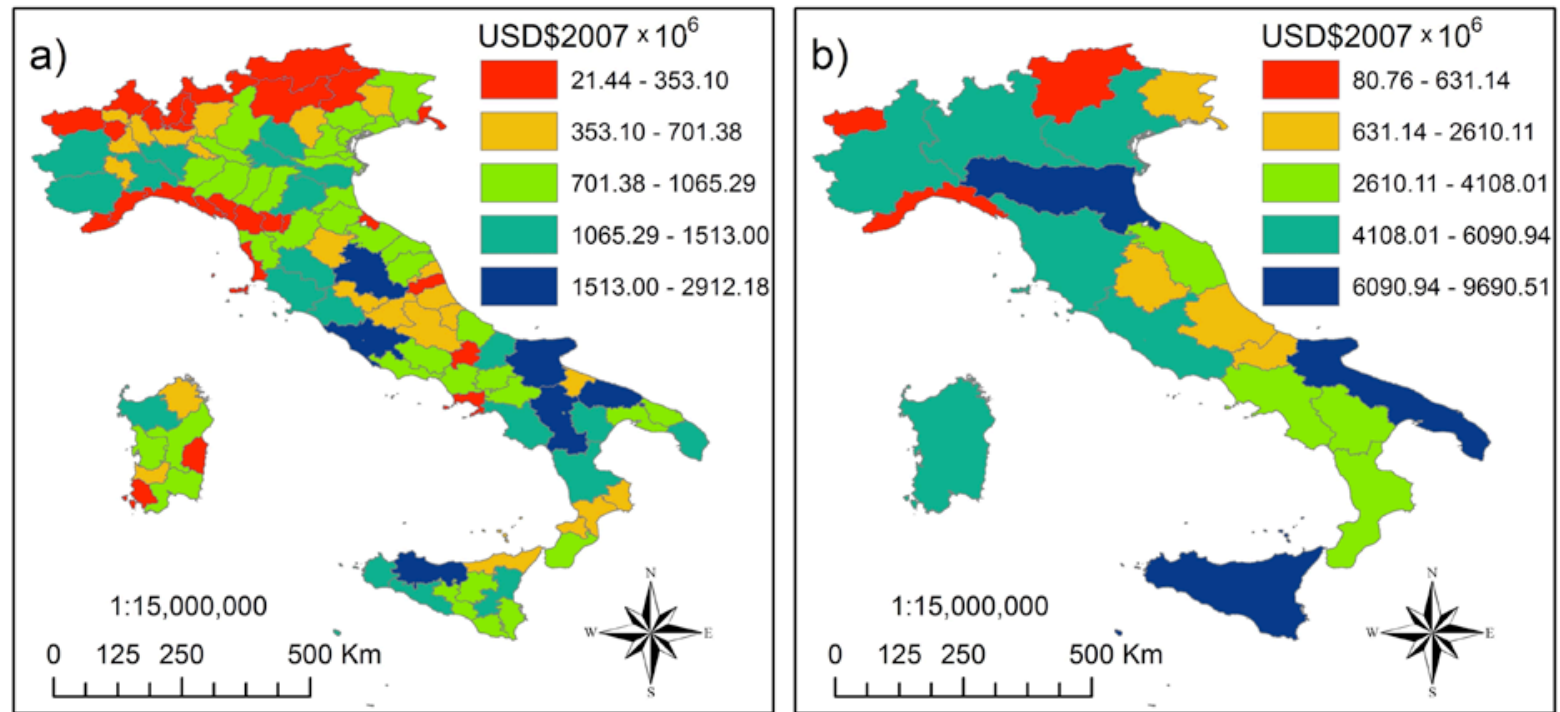

Figure 3: Total contribution of AESs in USD $\$ 2007$ a) at provincial level and b) regional level according to Costanza et al. [2] (Table 1).

the Italian agricultural land is estimated at 38.853 billion USD $\$ 2007$. This value is extremely close to the value provided by FAO verifying the values in Table 1 for AESs linked to the market. If we also assume that the rest values of Table 1 for the non-market AESs are realistic, then a respective $54.35 \%$ of the total estimated AESs can provide an estimation of the potential nonmarket contribution of Italian agricultural land in the national, regional and provincial economy. According to the above, the non-market value of AESs at national scale was estimated at $\sim 46.2$ billion USD $\$ 2007$, while estimations of the total non-market AESs at regional and provincial level are given in Tables 2 and $\mathbf{3}$. The multiplication of the total non-market AESs values of each region (Table 2) or province (Table 3 ) with the respective percentages given in Table 1 can provide estimations for each specific non-market AES.

The estimated potential value of non-market AESs at national level is extremely large. It is indicative that for the 15 out of 20 regions the non-market AESs value exceeds the 1 billion USD $\$ 2007$ while for the 39 out 110 provinces exceeds the 0.5 billion USD $\$ 2007$. Table 2 and 3 also provides the ranking of regions and provinces based on $P_{i}$ index. This ranking scheme can be used as tool to set priorities for the implementation of sustainable agronomic practices based on their contribution to non-market AESs. 
Table 2: Potential Contribution of Non-Market AESs in USD\$2007 in Italy at Regional Level and Priority Ranking for Implementing Sustainable Agricultural Practices at Regional Level Based on the $\boldsymbol{P}_{i}$ Index

\begin{tabular}{|c|c|c|c|c|c|c|c|}
\hline Rank & Region & $\begin{array}{l}\text { Non-Market AESs } \\
\text { (Million USD\$2007) }\end{array}$ & $P i$ & Rank & Region & $\begin{array}{l}\text { Non-Market AESs } \\
\text { (Million USD\$2007) }\end{array}$ & $P i$ \\
\hline 1 & Apulia & 4728.3 & 3.794 & 11 & Toscana & 2964.4 & 2.337 \\
\hline 2 & Sicily & 5266.8 & 3.653 & 12 & Basilicata & 1699.0 & 2.209 \\
\hline 3 & Emilia-Romagna & 4507.7 & 3.383 & 13 & Calabria & 2168.7 & 2.200 \\
\hline 4 & Veneto & 3063.1 & 2.654 & 14 & Molise & 818.1 & 1.998 \\
\hline 5 & Lazio & 2911.6 & 2.591 & 15 & Umbria & 1270.2 & 1.965 \\
\hline 6 & Lombardia & 3310.4 & 2.504 & 16 & Abruzzo & 1418.6 & 1.908 \\
\hline 7 & Sardegna & 3245.8 & 2.459 & 17 & Friuli Venezia Giulia & 907.8 & 1.684 \\
\hline 8 & Piemonte & 3246.4 & 2.415 & 18 & Liguria & 266.1 & 1.202 \\
\hline 9 & Marche & 1845.3 & 2.374 & 19 & Trentino-Alto Adige & 343.0 & 1.111 \\
\hline 10 & Campania & 2232.7 & 2.341 & 20 & Valle d'Aosta & 43.9 & $\sim 1.000$ \\
\hline
\end{tabular}

\section{DISCUSSION}

The estimated non-market AESs highlight the important economic contribution of agro-ecosystems that can be succeeded beyond food and raw materials production in the Italian agricultural land. Of course, for succeeding these values it is prerequisite to a) move towards more sustainable agricultural practices and b) to increase the awareness and willingness of politics, farmers, scientists, stakeholders and citizens nonrelated to agriculture to assess and exploit the economic benefits, which can be derived from non-market AESs. Such actions require high-level political interventions in local economies aiming to create a profitable interaction between the farmers and the rest society. The rest society should understand the economic benefits of such interactions and should support economically the farmers to move towards more sustainable practices that usually reduce their net agricultural income.

The last 25 years, the European countries have made a serious effort towards organic agriculture. Italy is one of the leading countries with the largest coverage of organic and in-conversion farming in Europe (http://faostat.fao.org) [46]. Apart from waste treatment, other benefits of this effort have already been identified in many areas of Italy and they are related to increase of biodiveristy [47], carbon sequestration [48] and recreation-agrotourism activities [49]. At the same time, Italy remains one of the top producers in terms of yields at European scale. This suggests that the total recommended ESs value for agricultural land provided by Constanza et al. [2] may underestimate the real capacity of Italian croplands for ESs since non-market regulation, supporting and cultural ESs are expected to be much higher. Future studies in Italian territory are necessary in order to assess the non-market economic effect of increased organic agriculture in the local economies in order to be used as a supporting tool for convincing authorities to promote and apply such activities.

As concern the amount of non-market AESs which can be derived by SEPs, the study provides potential estimations and ranking priorities for the implementation of SEPs for three different administrative scales: national, regional and provincial scale. It has to be noted that the smaller the administrative scale is, the larger are the errors of non-market AESs estimations due to more distinct a) differences in the intrinsic properties of agricultural land (e.g. climate, soil, topography), b) differences in the efficiency of SEPs due to crop type differences (e.g. irrigated or non-irrigated crops) c) differences of natural land types which coexist with agricultural land, d) differences in the available capital derived from other sources at administrative scale which can be used for investments and support of SEPs. All the above should be taken into account in order to build a multi-disciplinary approach for setting priorities for SEPs implementation based on criteria which will fairly disseminate both the profit of non-market AESs and the additional cost of SEPs.

\section{CONCLUSIONS}

The potential economic contribution of the nonmarket services at national, regional, and provincial level in Italy was assessed in this study. A simplified index-based method for setting priorities at different scales of administration units for the implementation of SAPs was also proposed. The results showed that the potential non-market value of AESs in Italy can reach 
Table 3: Potential Contribution of Non-Market AESs in USD\$2007 in Italy at Provincial Level and Priority Ranking for Implementing Sustainable Agricultural Practices at Provincial Level Based on the $\boldsymbol{P}_{\boldsymbol{i}}$ Index

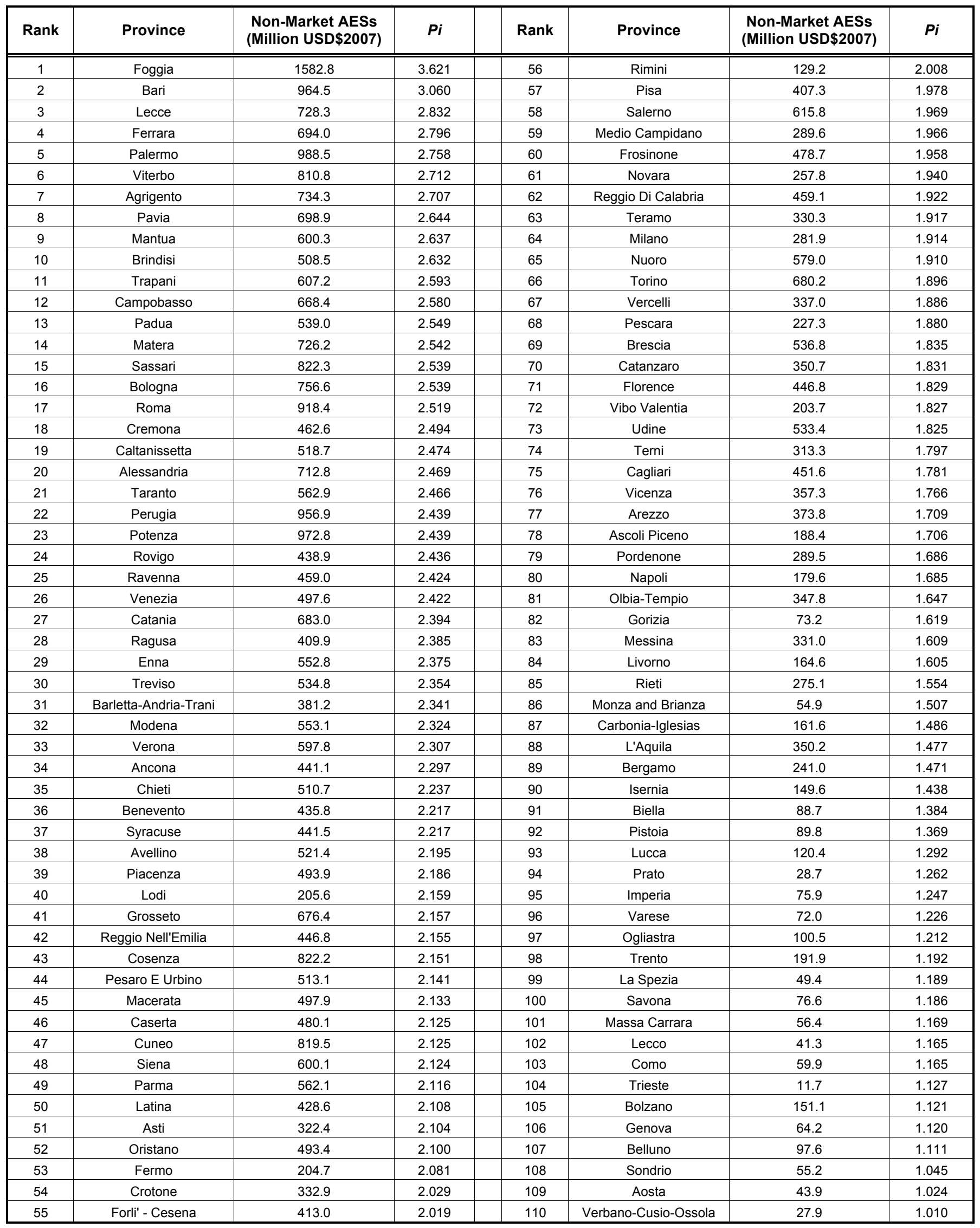


46.2 billion USD\$2007. This estimation shows that non-market AESs can play an important role in the national GDP. Finally, a priority ranking for the implementation of SAPs was proposed at regional and provincial level that can be a valuable decision support tool for promoting SAPs. Future studies are necessary in order to develop tools for assessing the variation of ESs within the agricultural ecosystems due to the high differences in environmental conditions, agronomic practices and crops. This would allow to better estimate the nonmarket ESs and their contribution in the local economies but also to create a more robust basis for developing and improving SAPs based on economical evidences that are more comprehensive to decision makers.

\section{REFERENCES}

[1] Costanza R, D'Arge R, De Groot R, Farber S, Grasso M, Hannon $B$, et al. The value of the world's ecosystem services and natural capital. Nature 1997; 387(6630): 253-260.

http://dx.doi.org/10.1038/387253a0

[2] Costanza R, de Groot R, Sutton P, van der Ploeg $S$, Anderson SJ, Kubiszewski l, et al. Changes in the global value of ecosystem services. Global Environ Chang. 2014; 26(1): 152-158.

http://dx.doi.org/10.1016/j.gloenvcha.2014.04.002

[3] de Groot R, Brander L, van der Ploeg S, Costanza R, Bernard $F$, Braat $L$, et al. Global estimates of the value of ecosystems and their services in monetary units. Ecosyst Serv. 2012; 1(1): 50-61.

http://dx.doi.org/10.1016/j.ecoser.2012.07.005

[4] Gissi E, Burkhard B, Verburg PH. Ecosystem services: Building informed policies to orient landscape dynamics. Int $J$ Biodivers Sci Ecosyst Serv Manage. 2015; 11(3): 185-189.

http://dx.doi.org/10.1080/21513732.2015.1071939

[5] Power AG. Ecosystem services and agriculture: tradeoffs and synergies. Philos T Roy Soc B: Biol Sci. 2010; 365(1554): 2959-2971.

http://dx.doi.org/10.1098/rstb.2010.0143

[6] Porter J, Costanza R, Sandhu H, Sigsgaard L, Wratten S. The value of producing food, energy, and ecosystem services within an agro-ecosystem. AMBIO 2009; 38(4): 186-193.

http://dx.doi.org/10.1579/0044-7447-38.4.186

[7] Su BY, Chen SB, Li YG, Yang WY. Intercropping enhances the farmland ecosystem services. Acta Ecol Sin. 2013; 33(14): 4505-4514.

http://dx.doi.org/10.5846/stxb201204200574

[8] Renting $\mathrm{H}$, Marsden TK, Banks J. Understanding alternative food networks: Exploring the role of short food supply chains in rural development. Environ Plann A 2003; 35(3): 393-411. http://dx.doi.org/10.1068/a3510

[9] Ortmann GF, King RP. Research on agri-food supply chains in Southern Africa involving small-scale farmers: Current status and future possibilities. Agrekon 2010; 49(4): 397-41. http://dx.doi.org/10.1080/03031853.2010.526428

[10] Atchison JE. Present status and future potential for utilization of nonwood plant fibers - a worldwide review. TAPPI CA Rep. 1973; 2: 69-89.

[11] Md Tahir P, Ahmed AB, Saifulazry SOA, Ahmed Z. Retting process of some bast plant fibres and its effect on fibre quality: A review. BioResources 2011; 6(4): 5260-5281.
[12]

McKendry P. Energy production from biomass (part 1): overview of biomass. Bioresource Technol. 2002; 83(1): 37-46.

http://dx.doi.org/10.1016/S0960-8524(01)00118-3

[13] Gissi E, Gaglio M, Reho M. Sustainable energy potential from biomass through ecosystem services trade-off analysis: The case of the Province of Rovigo (Northern Italy). Ecosyst Serv. 2016; (in press) DOI: 10.1016/j.ecoser.2016.01.004. http://dx.doi.org/10.1016/j.ecoser.2016.01.004

[14] Ten Kate K, Laird SA. The commercial use of biodiversity: Access to genetic resources and benefit-sharing. Earthscan Publications Ltd, London - Sterling, VA, 2002; p.398.

[15] Reddy JM. Optimization of furrow irrigation system design parameters considering drainage and runoff water quality constraints. Irrig Sci. 1994; 15(2-3): 123-136.

http://dx.doi.org/10.1007/BF00187198

[16] Ramos MC, Martínez-Casasnovas JA. Impact of land leveling on soil moisture and runoff variability in vineyards under different rainfall distributions in a Mediterranean climate and its influence on crop productivity. J Hydrol. 2006; 321(1-4): 131-146.

http://dx.doi.org/10.1016/j.jhydrol.2005.07.055

[17] Zribi W, Aragüés R, Medina E, Faci JM. Efficiency of inorganic and organic mulching materials for soil evaporation control. Soil Till Res. 2015; 148: 40-45.

http://dx.doi.org/10.1016/j.still.2014.12.003

[18] Araya T, Nyssen J, Govaerts B, Deckers J, Cornelis WM. Impacts of conservation agriculture-based farming systems on optimizing seasonal rainfall partitioning and productivity on vertisols in the Ethiopian drylands. Soil Tillage Res. 2015; 148: 1-13.

http://dx.doi.org/10.1016/j.still.2014.11.009

[19] Ur Rehman O, Rashid M, Kausar R, Alvi S, Sajjad MR. Assessment of runoff and sediment losses under different slope gradients and crop covers in semi-arid watersheds. Soil Environ. 2015; 34(1): 75-81.

[20] Morgan JA, Follett RF, Allen Jr LH, Del Grosso S, Derner JD, Dijkstra $F$, et al. Carbon sequestration in agricultural lands of the United States. J Soil Water Conserv. 2010; 65(1): 6A$13 \mathrm{~A}$.

http://dx.doi.org/10.2489/jswc.65.1.6A

[21] Gissi E, Gaglio M, Reho M. Trade-off between carbon storage and biomass-based energy sources ecosystem services, the case study from the province of Rovigo (Italy). Ann Bot. 2014; 4: 73-81.

[22] Oenema O. Governmental policies and measures regulating nitrogen and phosphorus from animal manure in European agriculture. J Animal Sci. 2004; 82(E-Suppl): 196-206.

[23] Aschonitis VG, Lekakis EH, Petridou NC, Koukouli SG, Pavlatou-Ve A. Nutrients fixation by algae and limiting factors of algal growth in flooded rice fields under semi-arid Mediterranean conditions: Case study in Thessaloniki plain in Greece. Nutr Cycl Agroecosyst. 2013; 96(1): 1-13. http://dx.doi.org/10.1007/s10705-013-9573-x

[24] Rigby H, Clarke BO, Pritchard DL, Meehan B, Beshah F, Smith SR, et al. A critical review of nitrogen mineralization in biosolids-amended soil, the associated fertilizer value for crop production and potential for emissions to the environment. Sci Tot Environ. 2016; 541: 1310-1338.

http://dx.doi.org/10.1016/j.scitotenv.2015.08.089

[25] Castaldelli G, Soana E, Racchetti E, Vincenzi F, Fano EA, Bartoli M. Vegetated canals mitigate nitrogen surplus in agricultural watersheds. Agr Ecosyst Environ. 2015; 212: 253-262.

http://dx.doi.org/10.1016/j.agee.2015.07.009

[26] Flint ML, Dreistadt SH. Natural Enemies Handbook: The Illustrated Guide to Biological Pest Control. (Ed.Clark, J.K.) 
University of California Press, Division of Agriculture and Natural Resources. 1998; Pub. 3386: p.154.

[27] Orr D. Biological control and integrated pest management. In: Integrated Pest Management. Vol. 1. Innovation-Development Process. (Eds. Peshin, R., Dhawan, A.K.). Springer, Dordrecht, The Netherlands, 2009; 207-240.

http://dx.doi.org/10.1007/978-1-4020-8992-3_9

[28] Nicholls $\mathrm{Cl}$, Altieri MA. Plant biodiversity enhances bees and other insect pollinators in agroecosystems - A review. Agron Sustain Dev. 2013; 33(2): 257-274.

http://dx.doi.org/10.1007/s13593-012-0092-y

[29] Hajjar R, Jarvis DI, Gemmill-Herren B. The utility of crop genetic diversity in maintaining ecosystem services. Agr Ecosys Environ. 2008; 123(4): 261-270.

http://dx.doi.org/10.1016/j.agee.2007.08.003

[30] Berthelin J, Leyval C, Laheurte F, De Giudici P. Involvement of roots and rhizosphere microflora in the chemical weathering of soil minerals. Plant Root Growth 1991; 187-210.

[31] Li Y, Zhang Q, Wan G, Huang R, Piao H, Bai L, et al. Physical mechanisms of plant roots affecting weathering and leaching of loess soil. Sci Chin Ser D Earth Sci. 2006; 49(9): 1002-1008.

http://dx.doi.org/10.1007/s11430-006-1002-4

[32] Leake JR, Duran AL, Hardy KE, Johnson I, Beerling DJ, Banwart SA, et al. Biological weathering in soil: The role of symbiotic root-associated fungi biosensing minerals and directing photosynthate-energy into grain-scale mineral weathering. Mineralogic Magaz. 2008; 72(1): 85-89.

http://dx.doi.org/10.1180/minmag.2008.072.1.85

[33] Rawitz E, Hadas A, Etkin H, Margolin M. The effect of various residue mulch-tillage combinations on soil physical conditions and performance of irrigated cotton. Soil Till Res. 1994; 32(4): 347-366.

http://dx.doi.org/10.1016/0167-1987(94)00419-F

[34] Maurya PR. Effect of tillage and residue management of maize and wheat yield and on physical properties of an irrigated sandy loam soil in Northern Nigeria. Soil Till Res. 1986; 8(C): 161-170.

http://dx.doi.org/10.1016/0167-1987(86)90331-4

[35] Fuentes M, Govaerts B, De León F, Hidalgo C, Dendooven L, Sayre KD, et al. Fourteen years of applying zero and conventional tillage, crop rotation and residue management systems and its effect on physical and chemical soil quality. Eur J Agron. 2009; 30(3): 228-237.

http://dx.doi.org/10.1016/j.eja.2008.10.005

[36] Swinton SM, Lupi F, Robertson GP, Hamilton SK. Ecosystem services and agriculture: Cultivating agricultural ecosystems for diverse benefits. Ecol Econ. 2007; 64 (2): 245-252.

http://dx.doi.org/10.1016/j.ecolecon.2007.09.020

[37] Van Berkel DB, Verburg PH. Sensitising rural policy: Assessing spatial variation in rural development options for Europe. Land Use Policy 2011; 28 (3): 447-459.

http://dx.doi.org/10.1016/j.landusepol.2010.09.002
[38] Fleischer A, Tsur Y. Measuring the recreational value of agricultural landscape. Eur Rev Agr Econ. 2000; 27(3): 385398.

http://dx.doi.org/10.1093/erae/27.3.385

[39] Geiger F, Bengtsson J, Berendse F, Weisser WW Emmerson M, Morales MB, et al. Persistent negative effects of pesticides on biodiversity and biological control potential on European farmland. Bas App Ecol. 2010; 11(2): 97-105. http://dx.doi.org/10.1016/j.baae.2009.12.001

[40] Konikow LF, Kendy E. Groundwater depletion: A global problem. Hydrogeol J. 2005; 13(1): 317-320.

http://dx.doi.org/10.1007/s10040-004-0411-8

[41] Colombani N, Mastrocicco M, Giambastiani BMS. Predicting Salinization Trends in a Lowland Coastal Aquifer: Comacchio (Italy). Water Res Manage. 2015; 29(2): 603-618.

http://dx.doi.org/10.1007/s11269-014-0795-8

[42] Withers PJA, Neal C, Jarvie HP, Doody DG. Agriculture and eutrophication: Where do we go from here? Sustainability. 2014; 6(9): 5853-5875.

http://dx.doi.org/10.3390/su6095853

[43] Reay DS, Davidson EA, Smith KA, Smith P, Melillo JM, Dentener $\mathrm{F}$, et al. Global agriculture and nitrous oxide emissions. Nature Clim Change. 2012; 2(6): 410-416.

http://dx.doi.org/10.1038/nclimate1458

[44] Pitman M, Läuchli A. Global impact of salinity and agricultural ecosystems. In: Salinity: Environment-Plants-Molecules, Springer, The Netherlands, A. Läuchli, U. Lüttge (Eds.) 2002; pp. 3-20.

[45] Stringer L. Can the UN Convention to Combat Desertification guide sustainable use of the world's soils? Front Ecol Environ. 2008; 6(3): 138-144. http://dx.doi.org/10.1890/070060

[46] Gamboni M, Moscatelli S. Organic agriculture in Italy: challenges and perspectives. Organic Agr. 2015; 5(3): 165-177. http://dx.doi.org/10.1007/s13165-015-0098-2

[47] Genghini M, Gellini S, Gustin M. Organic and integrated agriculture: The effects on bird communities in orchard farms in northern Italy. Biodivers Conserv. 2006; 15(9): 3077-3094. http://dx.doi.org/10.1007/s10531-005-5400-2

[48] Lazzerini G, Migliorini P, Moschini V, Pacini C, Merante P Vazzana C. A simplified method for the assessment of carbon balance in agriculture: An application in organic and conventional micro-agroecosystems in a long-term experiment in Tuscany, Italy. Ital J Agron. 2014; 9(2): 55-62. http://dx.doi.org/10.4081/ija.2014.566

[49] Privitera D. Combining organic agriculture and recreation: Evidence from Italy. Agricultural Management Strategies in a Changing Economy 2015; 301-317. 